\title{
ACUTE KIDNEY INJURY IN NEWBORNS
}

\author{
Silvana Naunova Timovska ${ }^{1}$, Svetlana Cekovska ${ }^{2}$, Katerina Tosheska-Trajkovska ${ }^{2}$ \\ ${ }^{1}$ University Children's Hospital-Skopje \\ ${ }^{2}$ Department of Medical and Experimental Biochemistry, Medical faculty Skopje, R. Macedonia \\ Corresponding Author: Silvana Naunova Timovska, University Children's Hospital, Skopje, R. Macedonia, \\ Tel. 0764545 76; Email: silvanatimovska@ yahoo.com
}

\begin{abstract}
Objective: Acute kidney injury is common condition in the neonatal intensive care unit and it is associated with poor outcome. The incidence of neonatal AKI is the highest one followed by adults and children, depending on different factors such as the gestational age, birth weight, contributing conditions and the facilities of the neonatal intensive care unit. The aim of the study was to determine the incidence, risk factors and the outcome of the neonatal acute kidney injury.

Subjects and Methods: This was a clinical, prospective study that was performed in a referent NICU at the University Children's Hospital in Skopje. All neonates admitted from January 2012 to December 20014 with documented acute kidney injury were included. The medical data records of the admitted neonates with AKI were analyzed. The material was statistically processed using methods of the descriptive statistics.

Results: During the study period 770 newborn infants were admitted to the NICU and $50(6.5 \%)$ infants developed acute kidney injury. The male to female ratio was 2.1:1. Most of the neonates involved in the study were neonates born at term (62\%). Oliguric AKI was found in 28 cases (56\%) and no oliguric in 22 cases (44\%). The prevalence of prerenal, renal and post renal AKI were $78.5 \%$, $19.5 \%$ and $2.0 \%$ respectively. Perinatal asphyxia was the most common predisposing factor for AKI and was evaluated in $38 \%$ of the cases with predominance of term infants and male. The mortality rate was $32 \%$ and was significantly higher in the group of patients with congenital heart diseases. Conclusion: AKI is a life threatening condition with still high mortality rate. Early recognition of the risk factors and the rapid effective treatment of the contributing conditions will reduce AKI in the neonatal period.
\end{abstract}

Key words: acute kidney injury, newborns, predisposing factors

\section{Introduction}

Acute kidney injury (AKI) is a serious condition which damages the kidney as a central mediator of the homeostasis of bodily fluids and electrolytes. It is common in patients in the neonatal intensive care unit (NICU) and it is associated with poor outcome. Because of the need of earlier detection of the disease, the term acute renal failure has been changed in to acute kidney injury.

It is characterized by a sudden deterioration of the normal kidney function. This dys- function causes abnormal regulation of bodily fluids and electrolytes. It occurs as a rapid decrease in glomerular filtration rate (GER) that leads to retention of the creatinine and the nitrogenous waste products and usually with a decrease in the urine output [1-6].

Acute kidney injury can also present with normal urine output (UO) especially in asphyxiated neonates. More than $40 \%$ of the infants have no oliguric AKI. Namely, the neonates have higher total body water content than adults. Especially in preterm infants, the total 
body water can be as high as $80 \%$ of the bodyweight. This discrepancy in the body water content, alongside with the immature tubular function is the reason why neonates have higher urine output than other age groups. It was proven that urine output level less than $0.5 \mathrm{~mL} / \mathrm{kg}$ per hour is not a sensitive marker of the neonatal AKI and must be increased up to $1.0 \mathrm{~mL} / \mathrm{Kg}$ per hour. [7-8]

Acute kidney injury occurs in 2 to $8 \%$ of the adult patients hospitalized in the intensive care units and the mortality rate is up to $50 \%$. In children, the incidence of AKI is significantly lower except in newborns where it occurs in 8 to $24 \%$ with mortality rates between $10 \%$ and 61\%. [9-10]

The risk factors for development of the neonatal acute kidney injury include very low birth weight (less than 1,500 g), low 5-minute APGAR score, intubation at birth, respiratory distress syndrome and neonatal medication administration (nonsteroidal anti-inflammatory drugs, antibiotics).

The causes of acute kidney injury in newborn infants are multiple and can be divided as prerenal, renal and post renal. Prerenal azotaemia is the most common type of acute kidney injury in newborns. It occurs in over $80 \%$ of cases, as a result of the inadequate renal perfusion, which, if promptly treated, is followed by improvements in renal function and urine output. Intrinsic (renal) kidney injury may occur due to parenchymal kidney damage. The post-renal kidney injury is a consequence of the urinary tract obstruction with inappropriate urine elimination. [11-12]

Predisposing factors may manifest as certain clinical conditions such as perinatal asphyxia, neonatal sepsis, prematurity, congestive heart failure and congenital anomalies, therapeutic interventions and certain nephrotoxic drugs. The appropriate treatment of the associated comorbidities, the reduction in the use of the potential nephrotoxic drugs reduce the risk of acute kidney injury in neonatal population in the intensive care units. [13-15]

The aim of the study was to determine the incidence, risk factors and outcome of the neonatal acute kidney injury.

\section{Subjects and Methods}

This is a clinical, prospective study that was performed in a referent neonatal intensive care unit at the University Children's Hospital in Skopje, Republic of Macedonia. All neonates admitted from January 2012 to December 20014 with documented acute kidney injury were included.

AKI was defined by progressive increase in the infant's plasma creatinine level higher than $130 \mathrm{umol} / \mathrm{L}$ in infants younger than 33 weeks of gestation and higher than $90 \mathrm{umol} / \mathrm{L}$ in infants older than 33 weeks of gestation. The presence of oliguria was defined as a urinary output less than $1.0 \mathrm{ml} / \mathrm{kg} / \mathrm{h}$. Non oliguric AKI was defined when urine output was more than $1.0 \mathrm{ml} / \mathrm{kg} / \mathrm{h}$ with abnormal renal functions.

According to the adopted criteria all infants who had major congenital abnormalities and infants who were under 25 weeks of gestation and older than 28 days of age were excluded from the study.

The medical data records of the admitted neonates with kidney injury were analyzed. Most of the laboratory examinations (serum creatinine, blood urea nitrogen, sodium, potassium, calcium, phosphorus, bicarbonate, total protein, albumin and urinalysis) were done in the biochemical laboratory of the Children's Hospital using Kodak camera dry biochemistry. We used tests for tubular function (concentration of sodium in the urine, renal failure index and fractional excretion of sodium) in differentiating between pre-renal and renal AKI.

All cases of newborn infants with kidney injury were analyzed according to the following criteria: gender, gestational age, birth weight and risk factors such as sepsis, asphyxia, prematurity with respiratory distress, heart congenital anomalies and heart failure that were associated with kidney injury.

The data collected were statistically analyzed. The quantitative variables were expressed as means and standard deviations, lower, higher and median values. The variables within category were described by their absolute (n) and relative (\%) frequencies. The association between the different variables was analyzed by appropriate hypothesis testing (Pearsons Chi-square, Kruskal-Wallis). Statistical signifi- 
cance (significance) was determined for the levels $\mathrm{p}<0.05$ and $\mathrm{p}<0.001$.

\section{Results}

The study was carried out at the neonatal intensive care unit at the University Children's Hospital Skopje in which all newborns with acute kidney injury were referred from the territory of Republic Macedonia. The whole study has been performed during a 3 year period.

Acute kidney injury was diagnosed in $6.5 \%$ (50 cases) of all 770 admitted newborn infants. According to the distribution by gender, it reflects the predominance of males in 32
(68\%) compared to females in $16(32 \%)$. The male to female ratio was $2.1: 1$.

Most of the newborn infants involved in the study were term infants $31(62 \%)$. Nineteen cases $(38 \%)$ were prematurely born. The demographic characteristics of the newborn infants are summarized in Table 1.

Oliguric AKI was found in 28 patients (56\%) and no oliguric in 22 patients $(44 \%)$. The prevalence of prerenal, renal and postrenal AKI were $78.5 \%, 19.5 \%$ and $2.0 \%$ respectively. The commonest cause of AKI in neonates was prerenal AKI, which may result in intrinsic kidney injury if not treated promptly. Table 2 shows the distribution of AKI types.

Table 1

Demographic characteristics of hospitalized neonates

\begin{tabular}{lccc}
\hline & Mean \pm SD & Min & $\max$ \\
\hline Age (days) & $4.49 \pm 5.7$ & 2 & 28 \\
Gestational age (wk) & $37.34 \pm 3.01$ & 26 & 40 \\
Weight (gr) & $2890.80 \pm 898.12$ & 780 & 4850 \\
Duration of stay (days) & $12.82 \pm 8.42$ & 5 & 28 \\
\hline
\end{tabular}

Table 2

Distribution of the type of AKI

\begin{tabular}{lcc}
\hline & $\begin{array}{c}\text { Number of } \\
\text { patients (n) }\end{array}$ & percent \\
\hline Oliguric AKI & 28 & 56 \\
No oliguric AKI & 22 & 44 \\
Pre-renal AKI & 39 & 78.5 \\
Renal AKI & 10 & 19.5 \\
Post renal AKI & 1 & 2.0 \\
\hline
\end{tabular}

Prevalence and distribution of predisposing factors associated with AKI among neonatal patients are shown in Table 3 and Figure 1. Perinatal asphyxia was the most common associated contributing condition registered in $38 \%$, with predominance in males and infants born at term. It was common finding in the no oliguric AKI, related to a less severe renal injury, and had a better prognosis.

Mechanic ventilation, vasoactive drugs requirement and exposure to nephrotoxic drugs, increased the risk of acute kidney injury. The distribution of the therapeutic interventions and drug treatments of patients admitted to the intensive care unit who developed acute kidney injury and their prognostic factors are shown in the Table 4.

Table 3

Predisposing factors for AKI

\begin{tabular}{lcc}
\hline & $\begin{array}{c}\text { Number } \\
\text { of patients }\end{array}$ & Percent \\
\hline Asphyxia & 19 & 38 \\
Sepsis & 14 & 28 \\
Prematurity with RDSy & 12 & 24 \\
Congenital heart diseases & 5 & 10 \\
\hline
\end{tabular}

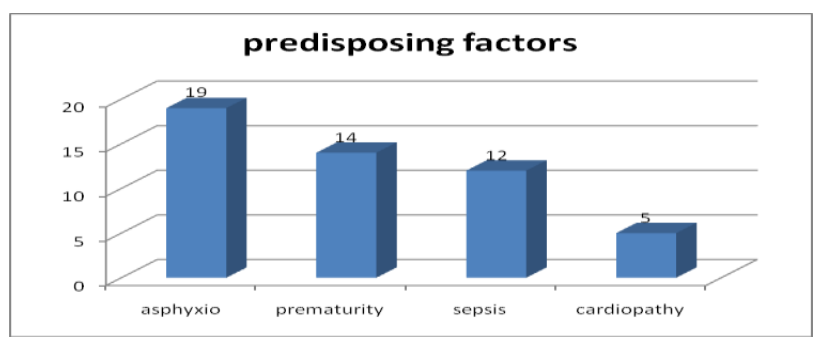

Figure 1 - Predisposing factors for AKI

The mortality among the hospitalized newborn infants with AKI was $32 \%$. It was significantly higher in the group of patients with 
congenital heart diseases than the other group $(P=0.01)$. Patients on assisted ventilation had significantly higher mortality rate. The distri-

Table 4 bution of mortality in predisposing factors associated with AKI are shown in Figure 2.

Distribution of therapeutic interventions, drugs administered and outcome in patients with AKI

\begin{tabular}{lcc}
\hline & Number of patients & Percent \\
\hline Oxygen supplementation & & \\
Yes & 18 & 36 \\
No & 32 & 64 \\
Assisted ventilation & & \\
Yes & 42 & 84 \\
No & 8 & 16 \\
\hline Vasoactive drugs & & \\
Yes & 29 & 58 \\
No & 21 & 42 \\
\hline Nephrotoxic drugs & & \\
Aminoglycoside & 32 & 64 \\
Vancomycin & 12 & 24 \\
Ceftazidime & 2 & 4 \\
Outcome & & 68 \\
Discharge & 34 & 32 \\
Death & 16 & \\
\hline
\end{tabular}

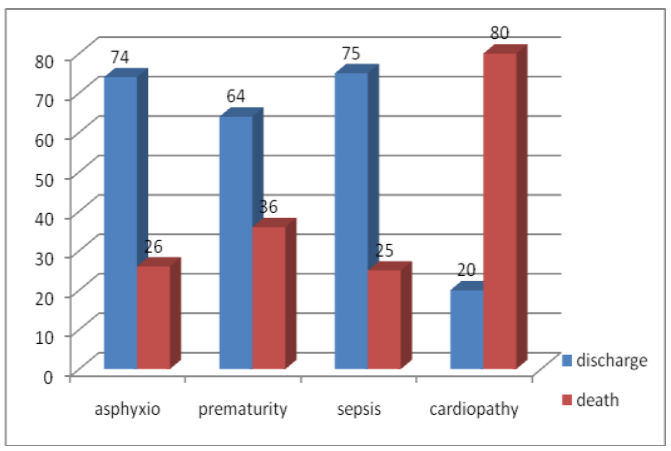

Chi-square $=58.5307 \quad \mathrm{P}=0 \mathrm{p}<0.01$

Figure 2-Distribution of mortality in predisposing factors associated with AKI

\section{Discussion}

The study was conducted at the University Children's Hospital in Skopje where most of the neonatal patients with documented acute kidney injury from the territory of R. Macedonia were referred. During the study period, 770 newborn infants were admitted to the NICU and 50 (6.5\%) infants developed acute kidney injury. These data correlate with the data described in several studies. [16-17] But we think that the incidence of neonatal AKI in our NICU is likely higher than it is reported in the present study. Namely, infants very often have non oliguric AKI. In the setting of normal urine output, AKI was unrecognized in some newborns (asphyxiated and preterm infants) and therefore they were not included the study. So, a significant number of newborn infants were missed according to the currently proposed definitions in the paediatric population.

According to the distribution by gender, the group of male infants dominated. The high prevalence of AKI in boys is probably the result of some predisposing factors such as neonatal sepsis and respiratory distress syndrome which are more common in male than female. [18-19] According to the distribution of the gestational age, the majority of the patients were infants born at term. The incidence of oliguria was $56 \%$ in our study, witch was in the reported range from $8 \%$ to $82 \%$ in recent studies. No nonoliguric AKI was associated with less morbidity and mortality than the oliguric AKI, probably because of the lesser degree and shorter duration of azotaemia. [20-23]

In $39 / 50(78.5 \%)$ of the patients prerenal azotaemia was registered as a result of the inappropriate renal perfusion. This finding cor- 
relates with the data presented in the studies of Ottonello et al. and Gopal et al. [24-25] Namely, Ottonello found prerenal azotemia in $85 \%$ of patients with neonatal AKI, while Gopal in $80 \%$ of patients. Due to the immaturity of the kidneys in neonates, poor renal perfusion may result in a secondary decrease in the renal function and finally in the acute kidney injury. Hence, arises the importance of timely and adequate treatment of neonates with kidney injury including the optimal hydration, treating contributing conditions, reducing nephrotoxic medications and invasive procedures. This approach leads to a substantially improved renal function, as well as the outcome and prognosis of the AKI [24-25].

Perinatal asphyxia is the most common contributing condition associated with AKI and was observed in $38 \%$ of the patients, with a predominance of males and term infants born with low Apgar score (in the first and fifth minutes of life). Abu-Haweleh et al. and Mortazavi et al. published similar findings in their studies as well. Abu-Haweleh reported that $42 \%$ and Mortazavi $30 \%$ of the patients with AKI have had perinatal asphyxia as a dominant contributing condition. [26-27] Different findings presented Kapoor et al. and Youssef et al. in their studies. Namely, Kapoor and Youssef found that neonatal sepsis was the commonest cause of AKI in $60 \%$ and $63 \%$ of patients with neonatal AKI respectively. [28-29]

The remaining patients in our study presented with the following associated conditions: sepsis $(28 \%)$, prematurity with respiratory distress syndrome (24\%) and congenital heart malformations $(10 \%)$. In all patients were registered more than one comorbid cause, indicating that the etiology of the acute kidney injury in the neonatal age is multifactorial. [3033]

The mortality rate was $32 \%$ and it correlates to the data presented in the studies of Gharehbaghi et al. and Mortazavi et al. [34-36] It was significantly higher in newborns with congenital heart disease and secondary development of sepsis, in which invasive therapeutic procedures such as intubations and assisted ventilation were applied. Special attention needs to be paid in the application of invasive procedures in neonates due to the association of these procedures with the risk of AKI. Critically ill newborns are at risk of having AKI, as they are commonly exposed to nephrotoxic medications and invasive therapeutic intervention such as assisted ventilation. [37-40]

\section{Conclusion}

AKI is a life threatening condition with still high mortality rate. It is an independent contributor to mortality. Often, the occurrence of kidney damage in the neonatal age is a result of multiple reasons. Early identification of newborns with acute kidney injury represents the first step in the prevention of this condition. Appropriate treatment of acute kidney injury, improves the outcome and prognosis. It reduces the morbidity and mortality of acute kidney injury in critically ill newborns and also reduces hospital stay and medical costs.

\section{REFERENCES}

1. Schrier W., Wang W., Poole B. et al. Acute renal failure: Definitions, diagnosis, pathogenesis, and therapy. J Clin Invest. 2004; 114: 5-14.

2. Weintraub AS, Carey A, Connors J, et al. Relationship of maternal creatinine to first neonatal creatinine in infants < 30 weeks gestation. J Perinatol. 2015; 35: 401.

3. Vieux R, Hascoet JM, Merdariu D, et al. Glomerular filtration rate reference values in very preterm infants. Pediatrics. 2010; 125: e1186.

4. Bateman DA, Thomas W, Parravicini E, et al. Serum creatinine concentration in very-low-birth-weight infants from birth to 34-36 wk postmenstrual age. Pediatr Res. 2015; 77: 696.

5. Subramanian S, Agarwal R, Deorari AK, et al. Acute renal failure in neonates. Indian J Pediatr. 2008: 75(4): 385-91.

6. Askenazi D. Evaluation and management of critically ill children with acute kidney injury. Curr Opin Pediatr. 2011; 23(2): 201-207.

7. Libório AB, Branco CM, Bezerra CT. Acute kidney injury in neonates: from urine output to new biomarkers. BioMed Research International. 2014, 2014: 601568 .

8. Bezerra CT, Vaz Cunha LC, Libório AB. Defining reduced urine output in neonatal ICU: importance for mortality and acute kidney injury classification. Nephrol Dial Transplant. 2013; 28(4): 901-9.

9. Morhal NE, Brocklebank JT, Maedow SR, et al. A review of acute reanal failure in children: incidence, etiology and outcome. Clin Nephrol. 40: 91-95.

10. Andreoli SP. Acute renal feilure in the newborn. Semin Perinatol. 2004; 8: 112-123. 
11. Joannidis M, Metnitz B, Bauer P, et al. Acute kidney injury in critically ill patients classified by AKIN versus RIFLE using the SAPS 3 database. Intensive Care Med. 2009 Jun 23.

12. Siew ED. and Deger SM., Recent advances in acute kidney injury epidemiology, Current Opinion in $\mathrm{Ne}$ phrology and Hypertension. 2012; vol. 21, no. 3, pp. 309-317.

13. Bresolin N., Bianchini AP., and Haas CA., Pediatric acute kidney injury assessed by pRIFLE as a prognostic factor in the intensive care unit, Pediatric Nephrology. 2013; vol. 28, no. 3, pp. 485-492.

14. Agras P, Tarcan A, Baskin E, et al. Acute renal failure in neonatal period, Ren Fail. 2004; 26(3): 305-9.

15. Bailey D, Phan V, Litalien C, et al. Risk factors of acute renal failure in critically ill children: A prospective descriptive epidemiological study, Pediatr Crit Care Med. 2007; 8: 29-35.

16. Askenazi D, Ambalavanan N and Goldstein S. Acute kidney injury in critically ill newborns: What do we know? What do we need to learn? Pediatr Nephrol. 2009; 24(2): 265-274.

17. Vachvanichsanong $\mathrm{P}, \mathrm{McNeil} \mathrm{E}$, Dissaneevate S, et al. Neonatal acute kidney injury in a tertiary center in a developing country. Nephrol Dial Transplant. 2012; 27(3): 973-7.

18. Akcan-Arikan A, Zappitelli M, Loftis LL, et al., Modified RIFLE criteria in critically ill children with acute kidney injury, Kidney Int. 2007; 71: 1028-35.

19. Gharehbaghi M. and Peirovifar A., Evaluating causes of acute renal failure in newborn infants Pak J Med Sci. 2007, Vol. 23, No. 6, 877-880.

20. Cataldi L, Leone R, Moretti U, et al. Potential risk factors for the development of acute renal failure in preterm newborn infants: a case-control study. Arch Dis Child Fetal Neonatal Ed. 2005; 90(6): F514-9.

21. Doronjski A, Stojanovic V, Spasojevic S, et al. Acute Renal failure in premature neonates. Vojnosanit Pregl. 2009; 66(11): 863-7.

22. Gupta BD, Sharma P, Bagla J, et al. Renal failure in asphyxiated neonates. Indian Pediatr. 2005; 42(9): 928-34.

23. Vishwanathan S, Manyam B, Azhibekou T, et al. Risk factors associated with acute kidney injury in extremely low birth weight (ELBW) infants. Pediatr Nephrol. 2012; 27(2): 303-11.

24. Ottonello G, Dessi A, Neroni P, et al. "Acute kidney injury in neonatal age " $\mathrm{J}$ of Pediatric and Neonatal I Medicine 2014; 3(2):e030246.

25. Gopal Girish, Acute kidney injury in perinatal asphyxia , Indian J. Pharm. Biol. Res. 2014; 2(2): 60-65.

26. Abu-Haweleh AF. Acute renal failure in newborn: etiology and mortality rate in Jordan patients. Saudi J Kidney Dis Transpl. 1998; 9: 18-21.

27. Mortazavi F, Hosseinpour S, and Nejati N., Acute kidney failure in neonatal period, Iran J Kidney Dis, 2009 Jul; 3(3): 136-40.
28. Kapoor K., Jajoo M., Dabas V et al. Predictors of mortality in neonates with acute renal failure Iran $\mathbf{J}$ Pediatr. 2013 Jun; 23(3): 321-326.

29. Youssef D, Abd-Elrahman H, Shehab N, et al. Incidence of acute kidney injury in the neonatal intensiven care unit, Saudi J Kidney Dis Transpl. 2015 Jan; 26(1): 67-72.

30. Andreoli SP. Acute kidney injury in children. Pediatr Nephrol. 2009; 24: 253-63.

31. Mak RH. Acute kidney injury in children: the dawn of a new era. Pediatr Nephrol. 2008; 23: 2147-9.

32. Zappitelli M, Parikh CR, Akcan-Arikan A, et al. Ascertainment and epidemiology of acute kidney injury varies with definition interpretation, Clin J Am Soc Nephrol. 2008; 3: 948-54.

33. Vachvanichsanong $\mathrm{P}$, Dissaneewate $\mathrm{P}$, Lim A, McNeil E, Childhood acute renal failure: 22-year experience in a university hospital in southern Thailand, Pediatrics, 2006; 118:e786-91.

34. Singbartl K. and Kellum J.A, AKI in the ICU: definition, epidemiology, risk stratification, and outcomes, Kidney International, vol. 81, no. 9, pp. 819$825,2012$.

35. Alkandari O, Eddington K.A., Hyder A. et al. Acute kidney injury is an independent risk factor for pediatric intensive care unit mortality, longer length of stay and prolonged mechanical ventilation in critically ill children: a two-center retrospective cohort study, Critical Care, vol. 15, no. 3, article R146, 2011.

36. Mammen C., Abbas A., Skippen P. et al. Long-term risk of CKD in children surviving episodes of acute kidney injury in the intensive care unit: a prospective cohort study, The American Journal of Kidney Diseases, vol. 59, no. 4, pp. 523-530, 2012.

37. Chertow GM, Burdick E, Honour M, et al. Acute kidney injury, mortality, length of stay, and costs in hospitalized patients, J Am Soc Nephrol. 2005; 16: 3365-70.

38. Otukesh H, Hoseini R, Hooman N, et al. Prognosis of acute renal failure in children. Pediatr Nephrol. 2006; 2: 1873-8.

39. Peng YQ, Liang QL, Shi W. Clinical characteristics and outcome evaluation of acute renal failure in critically ill patients in ICU. Chin J Pract Inter Med. 2007; 27: 1753-1755.

40. Bresolin N, Silva C, Halllal A, et al. Prognosis for children with acute kidney injury in the intensive care unit. Pediatr Nephrol. 2009; 24: 537-44. 
Резиме

\section{АКУТНО БУБРЕЖНО ОШТЕТУВАҢЕ КАЈ НОВОРОДЕНЧИҢАТА}

\section{Силвана Наунова Тимовска ${ }^{1}$, Светлана Цековска ${ }^{2}$, Катерина Тошеска-Трајковска ${ }^{2}$}

${ }^{1}$ Универзитетска клиника за детски болести, Скопје, Р. Македонија

${ }^{2}$ Институт за медицинска и експериментална биохемија, Медицински факултет Скопје, Р. Македонија

Boвеg: Акутното бубрежно оштетување е сериозна состојба кај новороденчињата во единица за интензивна нега и терапија и неретко е асоцирано со лош исход. Кај нив, инциденцијата на бубрежното оштетување е значително повисока во однос на преостанатите возрасни групи и зависи од повеќе различни фактори, како што се: гестациската возраст, родилната тежина, присутноста на коморбидни состојби, како и од условите и можностите во единицата за интензивна нега и терапија. Целта на студијата беше да ја утврди инциденцијата, факторите на ризик и исходот на бубрежно оштетување кај новороденчињата.

Майеријал и мет̄оgи: Се работи за клиничка, проспективна студија реализирана во Единицата за интензивна нега и терапија на Универзитетската клиника за детски болести во Скопје. Во студијата беа вклучени сите новороденчиња кај кои беше документирано акутно бубрежно оштетување во периодот од јануари
2012 година до декември 2014 година. При изработката на студијата ги користевме податоците од историјата на болеста на новороденчиња со бубрежно оштетување. Материјалот беше статистички обработен користејќи ги методите на дескриптивната статистика.

Резулйайи: Од вкупно 770 новороденчиња хоспитализирани на Одделот за интензивна нега и терапија, кај 50 новороденчиња (6.5\%) документиравме акутно бубрежно оштетување. Односот помеѓу машките и женските новороденчиња изнесуваше 2.1:1. Најголем дел од пациентите беа термински новороденчиња (62\%). Олигурично бубрежно оштетување беше регистрирано кај 28 пациенти (56\%), а неолигурично бубрежно оштетување кај 22 пациенти (44\%). Преваленциите на пререналното, реналното и постреналното АБО изнесуваа 78,5\%, 19,5\% и 2,0\%. Перинатална асфиксија беше најчестиот предиспонирачки фактор асоциран со бубрежното оштетување регистриран во $38 \%$ од случаите, со доминација на новороденчињата родени во термин и од машки пол. Стапката на смртност изнесуваше $32 \%$ и беше значително повисока кај пациентите со вродени срцеви болести.

Заклучок: Акутното бубрежно оштетување претставува животно загрозувачка состојба со с\# уште висока стапка на смртност. Раното препознавање на фактори на ризик и брзиот, ефикасен третман на коморбидните состојби доведуваат до намалување на бубрежното оштетување во неонаталниот период.

Клучни зборови: акутно бубрежно оштетување, новороденчиња, предиспонирачки фактори 